\title{
SZÁMÍTÓGÉPES GÉPTERVEZÉS OKTATÁSA MÉRNÖKÖKNEK
}

\author{
Szilvásiné Rozgonyi Erika \\ egyetemi docens, Gépészmérnöki és Informatikai Kar, Matematika Intézet, Ábrázoló Geometria Tanszék \\ 3515 Miskolc, Miskolc-Egyetemváros, e-mail: matre@uni-miskolc.hu
}

\begin{abstract}
Absztrakt
A CAD rendszer alatt több számitógépeken alapuló eszközt értünk, mely minden tervezési szakembert segit a tervezési folyamatban. Az elsö CAD szoftverek megjelenése az 1950-es évekre tehetö. Azóta már számos nem csak 2D-ben rajzoló, hanem 3D-ben szerkesztő alkatrésztervezö szoftver jelent meg. Ezek nélkül a mai mérnökök tervezési munkája már elképzelhetetlen. Egy ilyen nagyon elterjedt nagy teljesitménnyel biró CAD rendszer a PTC Creo Parametric, melynek rövid bemutatását olvashatjuk ezen cikkben.
\end{abstract}

Kulcsszavak: PTC Creo Parametric, számitógépes géptervezés, 3D modellek, CAD

\begin{abstract}
By CAD system we mean several computer based tools, it helps all design professionals in the design process. The first CAD software dates back to the 1950s. Since then, many parts design software has been published not only in $2 D$ but also in $3 D$. Without these, the design work of today's engineers is unimaginable. One such high-performance high performance CAD system is the PTC Creo Parametric, which is briefly described in this article.
\end{abstract}

Keywords: : PTC Creo Parametric, computer machine design, 3D modells, CAD

\section{Bevezetés}

Computer-aided design $(C A D)$ rendszer alatt több, számítógépen alapuló eszközt értünk, mely a mérnököket és más tervezési szakembereket a tervezési munkájukban segíti. A jelenleg használatos CAD programok a 2D (síkbeli) vektor-grafika alkalmazásától a 3D (térbeli) parametrikus felületés testmodellező rendszerekig a megoldások széles skáláját kínálják. Napjainkban a CAD szoftverek az építőmérnökök, építészmérnökök, villamosmérnökök, jármümérnökök és a gépészmérnökök legalapvetőbb tervezőeszközei. Egy ilyen tervező program az itt röviden bemutatott PTC Creo Parametric.

\section{Történelmi áttekintés}

Az 1950-es években elsőként megjelent CAD szoftverek 2D rajzolóprogramok voltak. Ezek tulajdonképpen egy intelligens rajztábla funkcióját töltötték be. Legismertebb és világszerte leggyakrabban használt képviselőjük az asztali számítógépekre készült AutoCAD, mely ma a világ talán legelterjedtebb CAD szoftvere. Az Autodesk céget 1982-ben alapította John Walker. Eredetileg vektorgrafikus rajzoló programnak indult AutoCAD Version 1.0 verzió 1982 decemberében jelent meg. Azóta számos verzió követte, sokszor néhány hónapon belül is újabb verziók kerültek piacra. Az egyik legfrissebb az AutoCAD 2019- 2018 márciusában vált elérhetővé. Ez a legújabb változat többek között 
támogatja a parametrikus blokkok használatát, a térbeli modellezést, a látványtervezést. Adatbázisok számára biztosítja a kivonatok készítését, rajzok és különböző adatbázisok dinamikus összekapcsolását, internetes közzétételi lehetőségeket biztosít, valamint különböző stílusokat is tudunk kezelni. Az elkészített modelleken akár ütközésvizsgálatot is végre lehet hajtani, mely segítségével igazolhatjuk, hogy a termék az alkatrészekből összerakható és terv szerint illeszkednek egymáshoz a komponensek. Többféle vizsgálat is végrehajtható, mint például kinematikai vagy dinamikai analízis. Véges elemes analízis is alkalmazható az alkatrészekre és az összeállításra, melynek segítségével többek között szilárdsági, dinamikai, termikus, áramlástani viszonyok ellenőrizhetők.

1958-ban holland-ír társulásként jött létre az Ascon Contractors cég, melyet BAM Contractors néven ismernek 2008-tól. Írország egyik legnagyobb építőmérnöki és középítési vállalata, mely az iparágak és szerteágazó projekttípusok kiszolgálására számos új technológiát vezetett be. Ezek között találhatjuk meg a számítógéppel segített géptervezés szoftvereit is, mint például a nagyon elterjedt Inventort, amely egy szintén professzionális szintü 3D tervezési és egyben dokumentációkészítési szoftver. Termékük parametrikus, szabadformájú, jól kezelhető és szerteágazó lehetőségeket kínál.

A B-rep test modellező matematikai programcsomagok (grafikus motorok) megjelenése (Parasolid és ACIS) az 1990-es évek eleje. Ez vezetett újabb közepes bonyolultságú szoftverek megjelenésére, mint például Solid Works megjelenése 1995-ben vagy a Solid Edge 1996-ban.

A PTC vállalatot 1985-ben alapították, melynek az első szoftverét 1988-ban készítették. Manapság az egyik legnagyobb és leggyorsabban növekvő technológiai vállalatként emlegetik. 1992-ben az óriási Caterpillar cég volt a legnagyobb megrendelőjük. A PTC Pro/Engineer CAD szoftverét 1993-ban a Creative Engineering Kft. vezette be a magyar piacra. A nemzetközi értékesítés látványos felívelése ellenére a Pro/Engineer hazai bevezetése nem indult zökkenőmentesen, méghozzá a magas ár miatt. A szoftver licence 25 ezer dollárba került, a futtatásához kínált munkaállomás közel ugyanennyibe. Első Pro/Engineer- ügyfelük az Electrolux volt, amelyet azóta már számos nagy cég, köztük az Ikarus és a Taurus követett.

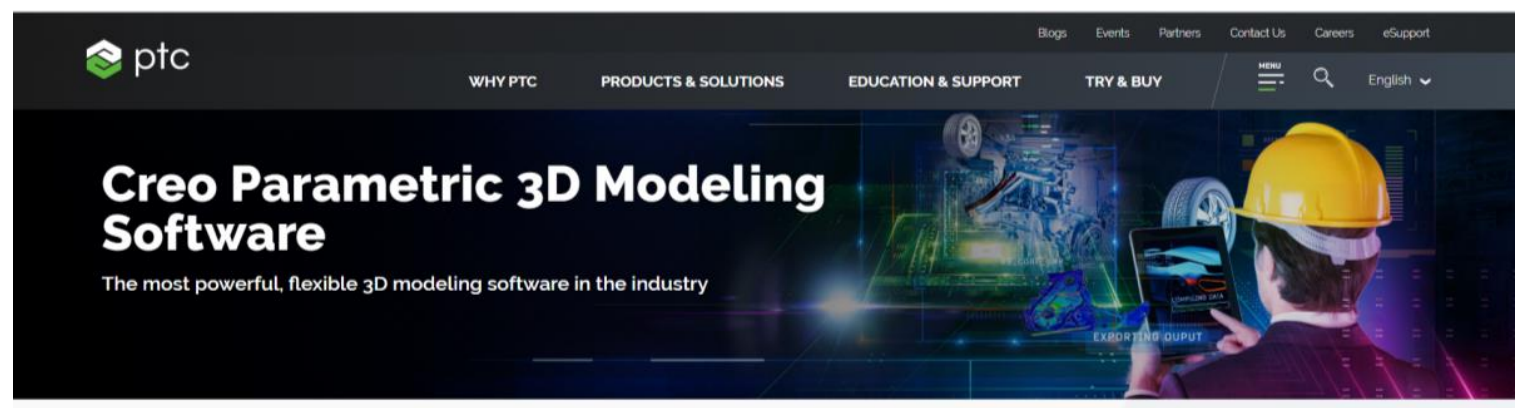

Design smarter. Starting now.

That's not just any product - it's yours. Creo Parametric has the core modeling strengths you'd expect from the industry leader, along

with breakthrough capabilities in additive manufacturing. model based definition (MBD) and smart connected design. Streamlined

workflows and an intuitive user interface complete the picture.

Put Creo Parametric 3D Modeling Software to work for you.

$-\div-\ldots=\ldots$

1.ábra Creo Parametric honlapja (https://www.ptc.com/en/products/cad/creo/parametric) 


\section{A Creo bemutatása}

A PTC Creo egy kompromisszumok nélküli átfogó rendszert kínál a tervező, fejlesztő és gyártó cégek számára. Rugalmas csomagrendszerével és az opcionálisan használható számos modul felhasználásával tökéletesen a felhasználók igényeire szabott. A light graphics opció a szoftverben lehetővé teszi számunkra, hogy pillanatok alatt töltsünk be akár több ezer alkatrészből készült összeállításokat, melyekkel utána dolgozni is tudunk, változtathatunk, elvehetünk vagy hozzáépíthetünk. A nagyon bö anyagválaszték, anyagjellemzők segítségével megadhatjuk és megnézhetjük, hogy hogyan nézne ki a kész alkatrészünk a valóságban. Az új alkatrészek létrehozása nagyon könnyü és többféle módon létrehozható a Creo segítségével. Egyik előnye, hogy akár a kész összeállitáshoz is közvetlenül elkészíthetjük az új alkatrészt, annak környezetében, ami jelentősen megkönnyíti munkánkat. A vázlatszerkesztő kezelése könnyü, automatikusan létrehozott geometriát a kényszerek alkalmazásával véglegesíthetjük, de bármelyik pillanatban a modellfa segítségével visszaléphetünk és megváltoztathatunk elöbb elkészített részelemeket. A rendszer azonnal jelzi, ha olyan változtatásokat teszünk, ami kihat az utána készített lépésekre. Nagy előnye, hogy minden változás azonnal megjelenik a modellhez kapcsolt müszaki rajzon és minden a müszaki rajzon végrehajtott változás azonnal megjelenik a 3D-ben elkészített modellen is. A méretek és kényszerek használatával biztosíthatjuk, hogy a tervező szándékának megfelelően tudjuk alakítani a már létrehozott alapgeometriát. Egyik jó tulajdonsága, hogy ha szükséges, akkor az elkészített geometriát tükrözhetjük, így minden, ami az egyik oldalon megjelenik, meg fog jelenni a másik oldalon is. A Creo egyik erös oldala, az összeállítások egyszerü és következetes kezelhetősége, más szoftverrel (NX, KTA, Solid Edge, Sold Works...) készített alkatrész további integrálás nélküli beilleszthetősége az éppen készülő összeállításba. Az összeállítás lehetséges hibáinak feltérképezésére is számos lehetőséget kínál. Ütközésvizsgálatot végezve a hiba közvetlenül ott a modellen kijavítható, mely javítás a müszaki rajzon is azonnal frissül. Alapvető szerkezeti analízist, kinematikai vizsgálatokat és a különböző mechanizmusok vizsgálatát is könnyedén elvégezhetjük. Így a tervezés közben elháríthatóak bizonyos hibák és ezen számítógépen elvégzett vizsgálatok segítségével a tervezö mérnökök könnyebben megérthetik, hogy az összeállítás, hogyan fog viselkedni a valóságban.

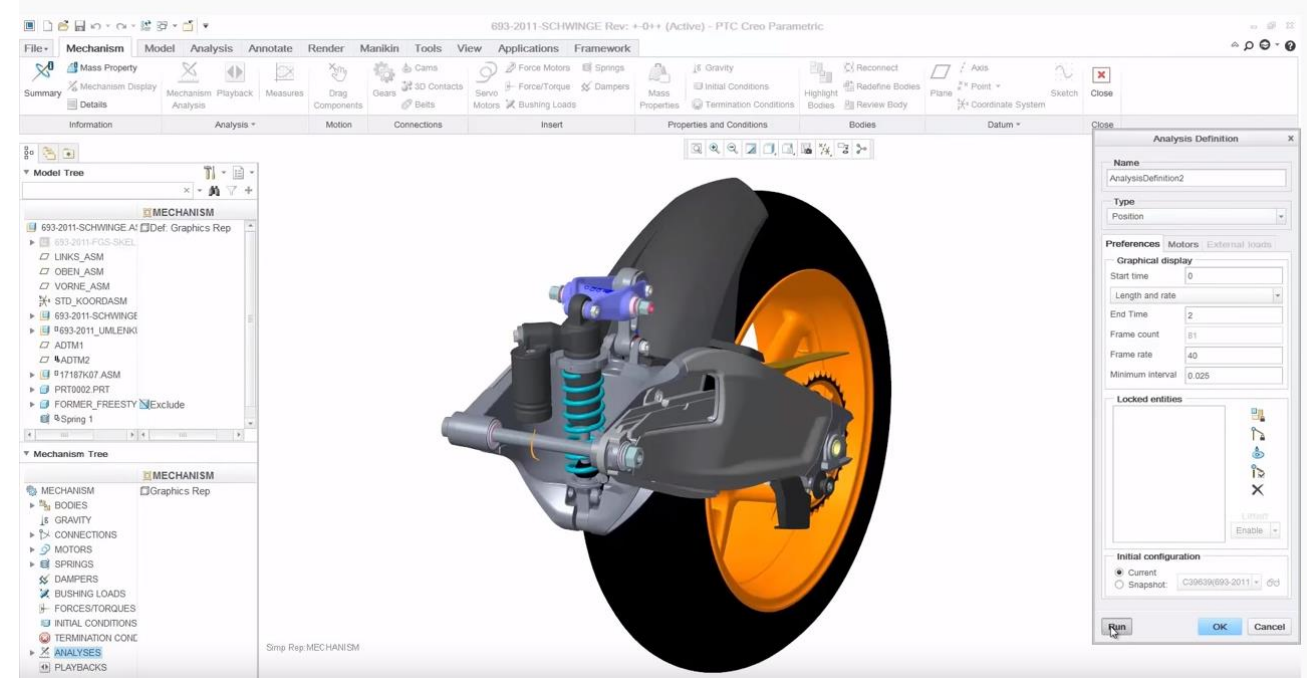

2.ábra Motor hátsó futómüje rugózásának kinematikai vizsgálata 
A beépített szabványos alkatrészek is jelentősen megkönnyítik a mérnökök munkáját. Az alkatrészek összeépítésére is számos variáció közül választhatunk. A lemezalkatrészeket a Creo Parametricben külön tervezői részben kezelhetjük a rájuk vonatkozó sajátságos jellemzőket kezelő felülettel, mint például a kiterített nézet elérhetősége minden pillanatban. A 3 dimenziós méretek használatával időt spórolhatunk a tervezés és a kivitelezésnél, így jóval kevesebb 2 dimenziós müszaki dokumentációra van szükség. A Creo nagyon sok választható kiegészítő alkalmazásokat kínál a felhasználó számára.

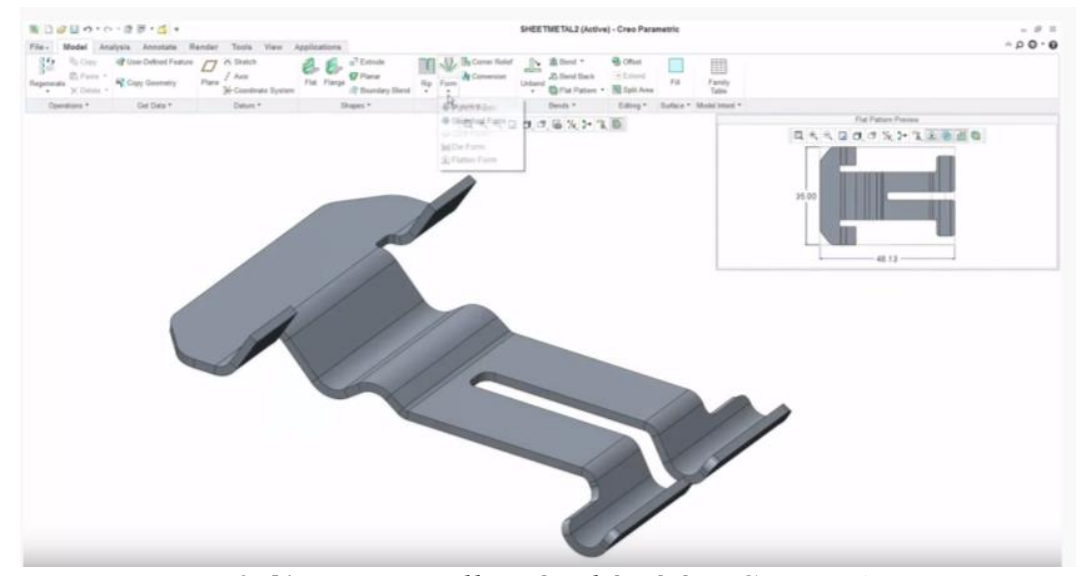

\section{3.ábra Lemezalkatrész készitése Creo-val}

Összegezve elmondhatjuk, hogy a Creo Parametric egy nagy teljesítménnyel bíró CAD rendszer, amely a számítógéppel segített tervezés teljes folyamatát lefedő termékfejlesztő szoftver. A beépített alkalmazásain és moduljain keresztül ez a szoftver és számos kiegészítő alkalmazásai egy teljes és egységes rendszert biztosítanak a felhasználónak a termékfejlesztés teljes folyamatában.

A Miskolci Egyetem Matematika Intézetének Ábrázoló Geometria Tanszékén több tantárgy keretén belül (Bevezetés a CAD-be, Cad alapjai) ezen professzionális szoftver legújabb (Creo 6.0) oktatói verzióját használva oktatjuk a gépészmérnök, logisztikai mérnök, jármümérnök és informatikus hallgatóknak a 2D rajzolás után a 3 D-s alkatrészek tervezését, majd azok müszaki rajzának elkészítését. A szoftver alapvető funkcióinak, mint menük, eszköztárak, modellfa megismerésével elősegítve a későbbi tervezői munkájukat. Az alapvető geometriai formákból (kör, négyzet, téglalap...) méretek és kényszerek megadásával hozzuk létre a kívánt formát.

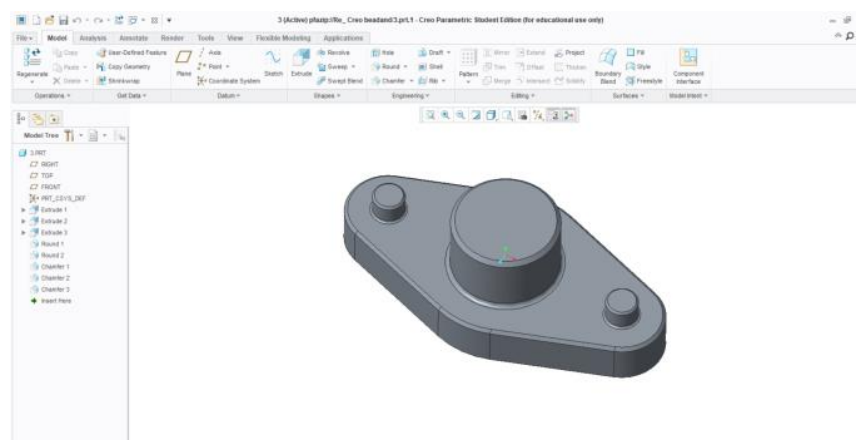

4.ábra Creo Parametric segitségével gyakorlaton elkészitett alkatrész 
A testek létrehozásánál megismertetjük a diákokat az extrudálás, a forgástest létrehozás továbbá a transzlációs testek elkészítésének módjaival, lehetőségeivel. Több alkatrészből készítünk összeállítást, melyen ütközésvizsgálatot is tekintünk. Megtanítjuk az elkészített alkatrész fotorealisztikus képének elkészítését, majd azok megjelenítését az anyagjellemzők megadása után. A hozzájuk kapcsolt müszaki rajzok pontos elkészítése is a feladatok között szerepel. Megismertetjük a diákokat azokkal a területekkel, ahol már használják ezt a nagy teljesítményü szoftvert.

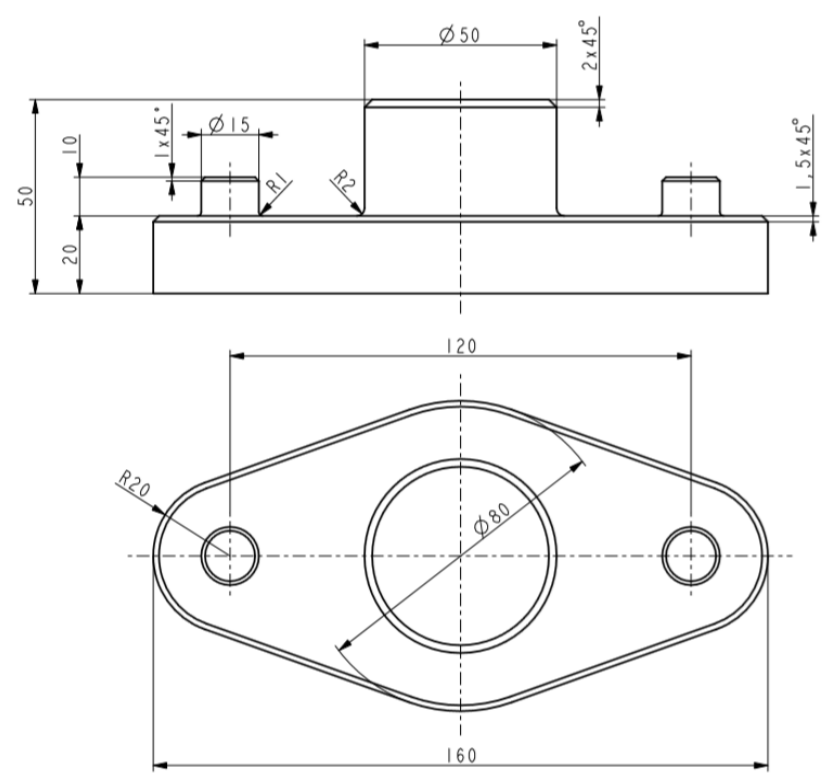

5. ábra Gyakorlaton elkészitett alkatrész (4. ábra) müszaki rajzának elkészitése Creo-val

\section{4. Összefoglalás}

Összességében elmondhatjuk, hogy pár évtized alatt (1950-es évektől kezdve) a 2D rajzoló programoktól kiindulva a számítógépes géptervezés egy nagyon professzionális, minden igényt kielégítő, az éppen adott termékfejlődési igényeknek megfelelő szintre jutott elősegítve a mérnökök tervezési munkáját. Számos olyan tervezőprogramot találunk a piacon, ami megfelel nemcsak az alkatrészek, összeszerelések, gépek létrehozásához, hanem további vizsgálatokkal is segíti az adott mérnök munkáját. Egy ilyen szoftver a PTC Creo Parametric, melynek legújabb 6.0 változatának néhány tulajdonságát ismertetjük itt röviden.

\section{Irodalom}

[1] https://www.ptc.com/en/products/cad/creo/parametric

[2] Sándor, L..: 3D-s modellek, elektronikus példatár, http://abrpc09.abrg.unimiskolc.hu/segedlet/dokumentumok/3D-s\%20modellek.pdf

[3] https://www.engineere.com/HU/Budapest/206119866078723/HungaroCAD

[4] https://www.youtube.com/watch?v=lBjreQg05fY 